\title{
Szemfenéki érfestés festélk nélkül: Az optikai koherencia tomográfia alapú angiográfia exsudativ típusú időskori maculadegenerációban
}

\author{
Resch Miklós dr. - Németh Csilla dr. - Barcsay György dr. \\ Ecsedy Mónika dr. - Borbándy Ágnes dr. - Géhl Zsuzsanna dr. \\ Balogh Anikó dr. - Szabó Antal dr. \\ Nagy Zoltán Zsolt dr. - Papp András dr. \\ Semmelweis Egyetem, Általános Orvostudományi Kar, Szemészeti Klinika, Budapest
}

\begin{abstract}
Bevezetés: Az időskori maculadegeneráció exsudativ formájának elfogadott és hatékony kezelése a vascularis endothelialis növekedési faktort gátló kezelés. Célkitüzés: Annak morfológiai leírása, milyen érrendszer észlelhető a macula területében több éve tartó tartós kezelés után. Módszer: A vizsgálatba 48 beteget ( 34 nő, 14 férfi, életkor 74,4 $\pm 8,0$ év) vontak be, akiknél legalább 24 hónappal korábban kezdték meg a vascularis endothelialis növekedési faktort gátló kezelést (ranibizumab, aflibercept). A kezelt 56 szemnél a követési idő (53,8 \pm 31,0 hónap) alatt összesen 7,6 \pm 4,9 injekciót alkalmaztak. AngioVue (Optovue Inc., Fremont, CA, Amerikai Egyesült Államok) készülékkel optikai koherencia tomográfia-angiográfia vizsgálatot végeztek. Eredmények: A felszínes retinaerek károsodását 5/56 esetben, a mélyebb retinakeringés kiesését 9/56 esetben tapasztalták. A choriocapillaris károsodására, az érújdonképződést követő eltérésekre négyféle kép volt a jellemző: 1. pigmenthám- és choriocapillaris-atrophia, 2. submacularis heg, 3. aktív neovascularisatio, 4. intraretinalis ciszták. Köpetkeztetés: Az optikai koherencia tomográfia-angiográfia noninvazív módszer, amelynek segítségével a maculadegeneráció jól nyomon követhető. Orv. Hetil., 2016, 157(42), $1683-1690$.
\end{abstract}

Kulcsszavak: maculadegeneráció, optikai koherencia tomográfia, angiográfia

\section{Angiography of the ocular fundus without dye: Optical coherence tomography based angiography in exsudative age-related macular degeneration}

Introduction: Vascular endothelial growth factor antibody therapy is an established treatment of exsudative age-related macular degeneration. Aim: The morphologic characterisation of the macular microvasculature after longstanding treatment. Method: Forty-eight patients ( 34 women and 14 men; age, $74.4 \pm 8.0$ years) were enrolled in the study. During follow-up time $(53.8 \pm 31.0$ months $), 7.6 \pm 4.9$ injections were administered in 56 eyes. Optical coherence tomography angiographic examination was performed with AngioVue (Optovue Inc. Fremont, CA, USA). Results: Distortion of the superficial retinal plexus and foveal avascular zone enlargement were noted in $5 / 56$ eyes, deep retinal plexus defect was detected in $9 / 56$ cases. Destruction of the choriocapillaries and the former neovascularisation could be found in 4 different patterns: 1. pigment epithelium and choriocapillary atrophy, 2. submacular scar, 3. active leaking choroidal neovascularisation, 4. intraretinal cysts. Conclusion: Optical coherence tomography angiography is a novel non-invasive method, which enables the follow up of macular degeneration.

Keywords: macular degeneration, optical coherence tomography, angiography

Resch, M., Németh, Cs., Barcsay, Gy., Ecsedy, M., Borbándy, Á., Gébl, Zs., Balogh, A., Szabó, A., Nagy, Z. Zs., Papp, A. [Angiography of the ocular fundus without dye: Optical coherence tomography based angiography in exsudative age-related macular degeneration]. Orv. Hetil., 2016, 157(42), 1683-1690.

(Beérkezett: 2016. június 15.; elfogadva: 2016. augusztus 9.) 


\section{Rövidítések}

$\mathrm{AMD}=$ (age-related macular degeneration $)$ időskori maculadegeneráció; $\mathrm{CNV}=$ chorioidealis neovascularisatio; $\mathrm{CRT}=$ (central retinal thickness) centrális retinavastagság; ETDRS = Early Treatment Diabetic Retinopathy Study (a diabeteses retinopathia korai kezeléséról szóló tanulmány); OCT = optikai koherencia tomográfia; OCT-A = optikai koherencia tomográfia-angiográfia; $\mathrm{VEGF}$ = vascularis endothelialis növekedési faktor

Az időskori maculadegeneráció (AMD) a vakság vezető okai között szerepel a fejlett országokban és hazánkban is [1]. A súlyos látásromlásért az esetek 90\%-ában az úgynevezett nedves (exsudativ) AMD a felelős, amely az AMD mintegy 20\%-ára jellemző. A betegség másik formája, az úgynevezett száraz (nem exsudativ), jóval gyakoribb (az esetek 80\%-ában ez fordul elő), viszont az jóval ritkábban okoz súlyos és hirtelen látásromlást. A két forma elkülönítése alapvető fontosságú, amelyre speciális szemfenéki vizsgálatok hivatottak. A szemfenéki vizsgálatok célja a látásromlást okozó, a retina alatt és a retina rétegei között megjelenő kóros folyadékgyülem, azaz az exsudatio forrásának, a subretinalis érhártyából kiinduló érújdonképződésnek a kimutatása (chorioidealis neovascularisatio- CNV) $[2,3]$.

Az exsudativ AMD-ben szenvedő betegek vizsgálatának része a CNV kimutatása. Ez hagyományos módon szemfenéki érfestéses vizsgálattal történik, amely során fluoreszcens vagy indocianin zöld festékanyag intravénás beadását követően sorozatfelvételeket készítünk a szemfenékről [4]. A másik alapvetően szükséges vizsgálóeljárás az optikai koherencia tomográfia (OCT), azaz szemfenéki rétegfelvétel, amely a retina keresztmetszeti képét mutatja meg. Az OCT-ről 1991-ben jelent meg az első közlés [5], hazai folyóiratban Békési [6] és Somfai mutatta be [7]. Az utóbbi években a mindennapi rutinvizsgálatoknál vizsgálóeszközként alkalmazott OCT előnye, hogy az angiográfiás vizsgálattal ellentétben nem invazív, így bármikor elvégezhető. Az OCT megmutatja a kóros folyadék jelenlétét és mennyiségét, de nem mutatja meg pontosan a fó kóros eltérést, a kóros érújdonképződést, így nem tudja teljesen kiváltani az érfestéses vizsgálatokat. A jelenleg aktuális ajánlás, az EURETINA 2014 szerint [8] a multimodális képalkotás a választandó, amely az OCT és a hagyományos angiográfiás felvételek együttes kiértékelését jelenti. Az optikai koherencia tomográfia-angiográfia (OCT-A) jelenleg hazánkban egyelőre nem elérhető a mindennapi gyakorlatban, világszerte sem terjedt el. Az OCT-A szerepe elsősorban kutatási vizsgálatokban van, ezért nem is szerepel még az AMD kezelési irányelveiben.

Az utóbbi években az OCT fejlesztése során növelni tudták a kép felbontását, a képalkotás pontosságát, a zavaró hatások (például szemmozgás) okozta képromlást, és automatizálták az egyes retinarétegek és struktúrák felismerését (szegmentáció). A fejlesztés legújabb eleme lehetővé tette a látóhártya egyes rétegeinek és az érhártya érrendszerének megjelenítését az OCT-felvételek speciális 3 dimenziós rekonstrukciója révén. Az új technológiát OCT-angiográfiának (OCT-A) nevezték el, neve kifejezi, hogy noninvazív, optikai elven múködő érrajzolatot kimutató képalkotó vizsgálat. Az első készüléket már 2006ban megalkotta Makita [9], de csak 2012-ben a Jia által fejlesztett készülék tette lehetővé a klinikai gyakorlatba kerülését elsősorban a szoftverek fejlesztése révén [10].

Az OCT-A képalkotása a dekorreláció alapelvén alapul, amely azt jelenti, hogy a készülék ugyanabban a síkban rövid idő alatt több felvételt készít, miközben az erekben áramló vörösvértestek elmozdulnak, addig a retina sejtjei és sejtmentes elemei mozdulatlanok maradnak. A sorozatfelvételek közötti különbség tehát csak a vörösvértestek elmozdulásában lesz, így a vörösvértestek által kitöltött arteriolák, kapillárisok és venulák jól láthatóvá válnak. Míg a hagyományos érfestés esetén a retina felszínes, mély érhálózatai és a choriocapillaris érhálózata egymásra vetülve jelenik meg, az OCT-A segítségével szegmentáció után az egyes érrétegek külön-külön ábrázolhatók. Az OCT-A-felvételek interpretációjára nem alkalmas a hagyományos fluoreszcens angiográfiás (FA) nevezéktan, ezért annak kialakítása folyamatban van, számos összehasonlító tanulmány látott napvilágot [11].

Az utóbbi évtizedben a nedves AMD kezelése sokat fejlődött, a rendszeresen adott intravitrealis biológiai gyógyszerek adása mellett a kóros érnövekedés visszaszorítható, így a nagyfokú látásromlás megakadályozható, mérsékelhető. Az AMD és az AMD-re adott kezelés hatására a CNV szerkezetében történő rövid távú változások nemrégiben kerültek rendszerszerü leírásra [12].

Közleményünk célja az exsudativ AMD miatt régóta vascularis endothelialis növekedési faktor (VEGF-) ellenes gyógyszerrel kezelt betegek adatainak ismertetése, annak bemutatása, hogy a szemfenék milyen OCT-angiográfiás jellegzetességekkel rendelkezik a tartós kezelés után. További célunk a vizsgálati módszer bemutatása magyar nyelven elsőként.

\section{Módszer}

\section{Betegek}

Egycentrumú keresztmetszeti vizsgálatot végeztünk. A Semmelweis Egyetem, Szemészeti Klinika Retina Szakrendelésén megjelenő gondozott betegek közül vizsgálatunkba 48 olyan beteget ( 34 nő, 14 férfi, életkor $74,4 \pm 8,0$ év) vontunk be, akiknél legalább 24 hónappal korábban kezdtük meg a VEGF-gátló kezelést exsudativ AMD miatt. (A legkorábban megkezdett kezelés 91 hónappal a vizsgálat előtt történt.) Kizártuk az 50 évnél fiatalabb betegeket és mindazokat, akiknél nem egyértelmúen az AMD talaján alakult ki az érújdonképződés (például patológiás myopia, angioid streaks vagy chorioretinitis). A 48 beteg 56 szemének adatait dolgoztuk fel. Csak azokat az eseteket elemeztük, amelyeknél megfelelő képminőség volt elérhető. 

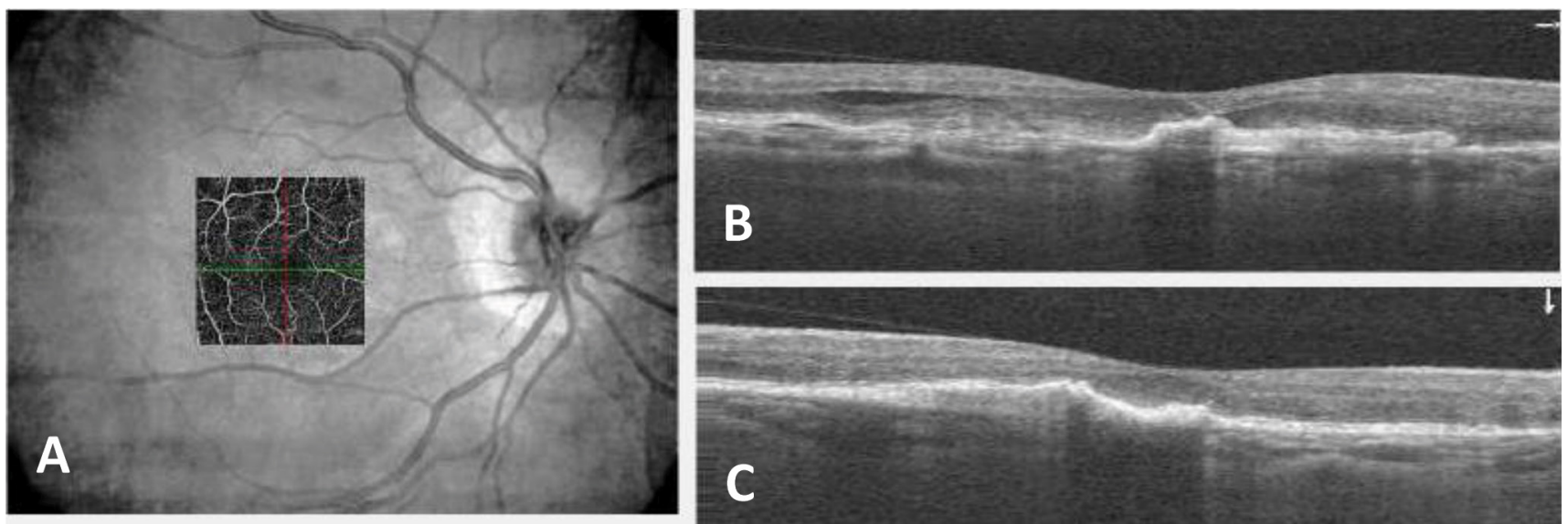

1. ábra

Az OCT-angiográfia képalkotó módszere. A) Az infravörös szemfenéki áttekintő felvételen fekete háttérrel látható a $10 \times 10^{\circ}$ négyzetben az angiográfiával ábrázolt terület. B) Horizontális síkú keresztmetszeti OCT-felvétel. C) Vertikális kép

\section{Kezelés}

Háromféle gyógyszeres kezelést alkalmaztunk: 34 szem esetében ranibizumab (Lucentis, Novartis), 16 szem esetében aflibercept (Eylea, Bayer) és 6 szem esetében mindkét gyógyszer adására sor került. A követési idő $(53,8 \pm 31,0$ hónap) alatt a betegek összesen 7,6 \pm 4,9 injekciót kaptak. A vizsgálat előtti utolsó kezelésre $14,0 \pm 18,7$ (1-88) hónappal a vizsgálat előtt került sor.

\section{Vizsgálatok}

Korábbi vizsgálatainkhoz hasonlóan minden betegnél meghatároztuk a legjobb korrigálható látóélességet ETDRS (Early Treatment Diabetic Retinopathy Study - a diabeteses retinopathia korai kezeléséról szóló tanulmány) -táblán $[13,14]$. Pupillatágítás után a réslámpás és a szemfenéki vizsgálatot végeztük el. AngioVue (Op- tovue Inc., Fremont, CA, Amerikai Egyesült Államok) készülékkel OCT-angiográfiás vizsgálatot végeztünk a foveára centráltan $10 \times 10^{\circ}$-os négyzet területében (1. ábra).

A készülék szoftvere (split-spectrum amplitude-decorrelation angiography - SSADA) algoritmust használva körülbelül 2,6 másodperc alatt 70 000/s A-scan felvételt készít $840 \mathrm{~nm}$ hullámhosszúságú fénnyel [15]. A felvételek során a készülék vízszintesen és függólegesen pásztázza végig a retina adott területét, amely alapján elvégzi a képrekonstrukciót. Automatikus szegmentációt végez és automatikusan „en face” rétegfelvételeket készít. Az így elvégzett szegmentáció során lehetőségünk nyílt az alábbi érrétegek elemzésére. Elemeztük a retina felszínes és mély rétegeinek plexusait, a külső retina és a choriocapillaris érrendszerét, valamint az en face OCTfelvételek jellegzetességeit (2. ábra).

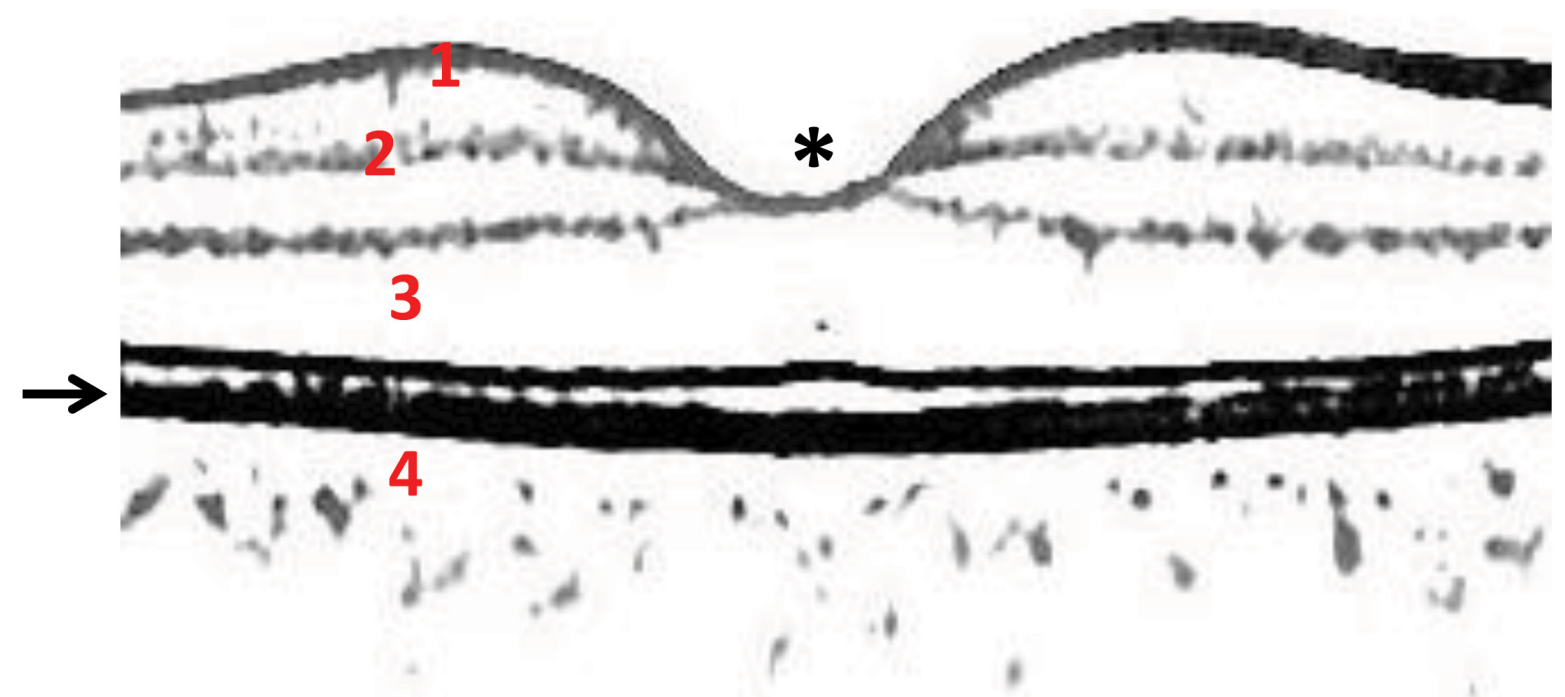

2. ábra

Sematikus ábra a macula keresztmetszetéról (az ábra OCT-felvétel átszerkesztésével készült). Középen a fovea behúzottsága látható (*), alul a pigmentepithelium (nyíl) és alatta a chorioidea. A számok az OCT-A által detektált rétegeket mutatják: 1 . felszínes retinaplexus, 2 . mély retinaplexus, 3. mély retinaréteg (normálisan avascularis), 4. choriocapillaris 


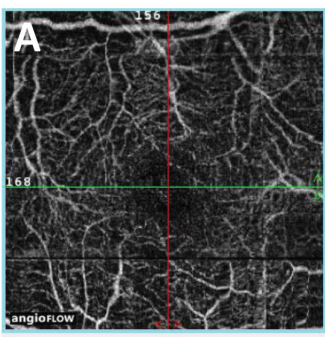

Angio / OCT - Superficial

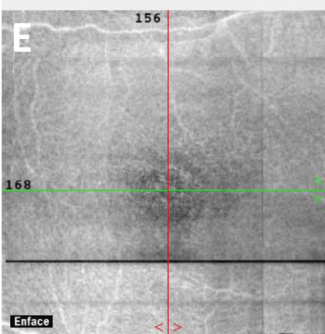

I

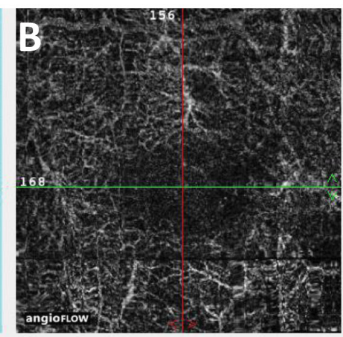

Angio / OCT - Deep

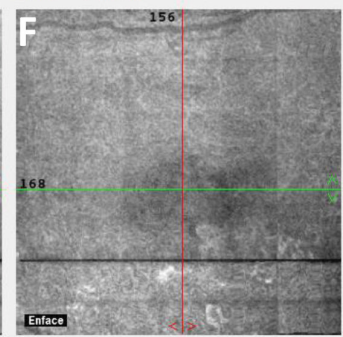

Enface
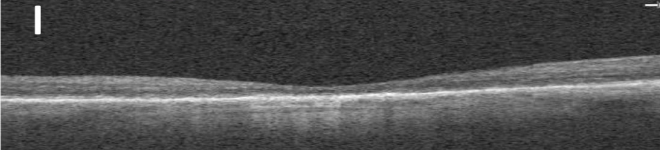

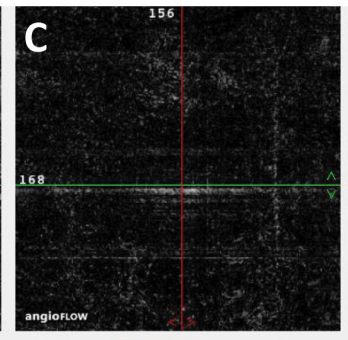

Angio / OCT - Outer Retina
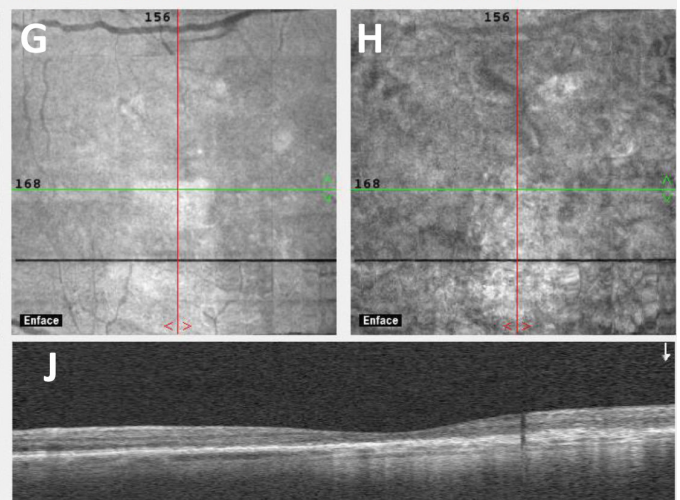

3. ábra

Jellemző kép kezelt AMD után: Tisztán sorvadásos forma. A)-D) OCT-A-felvételek. E)-H) En face OCT-felvételek. I)-J) OCT-felvételek

A) Felszínes retinaplexus - megtartott

B) Mély retinalis plexus - kiszélesedett fovealis avascularis zóna

C) A retina mély rétege - sejthető/belevetül a régi CNV

D) A choriocapillaris érhálózat - a vastagabb erekból felépülő korábbi, már inaktív CNV

E)-H) En face OCT-felvételek az A)-D) felvétel síkjában. A CNV síkjában egyenetlenség (H)

I)-J) Hagyományos OCT-felvételek a horizontális és vertikális síkokban. Elvékonyodott neuroretina és pigmenthám

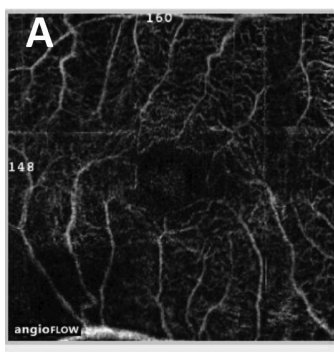

Angio / OCT - Superficial
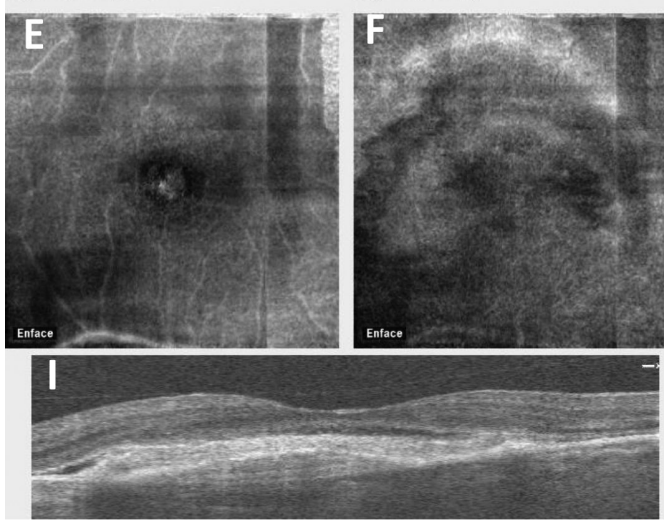

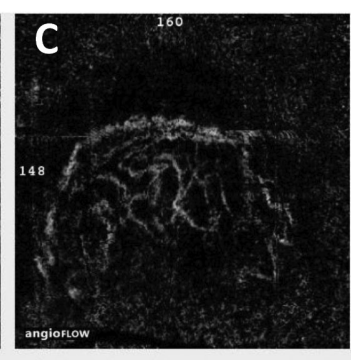

Angio / OCT - Outer Retina
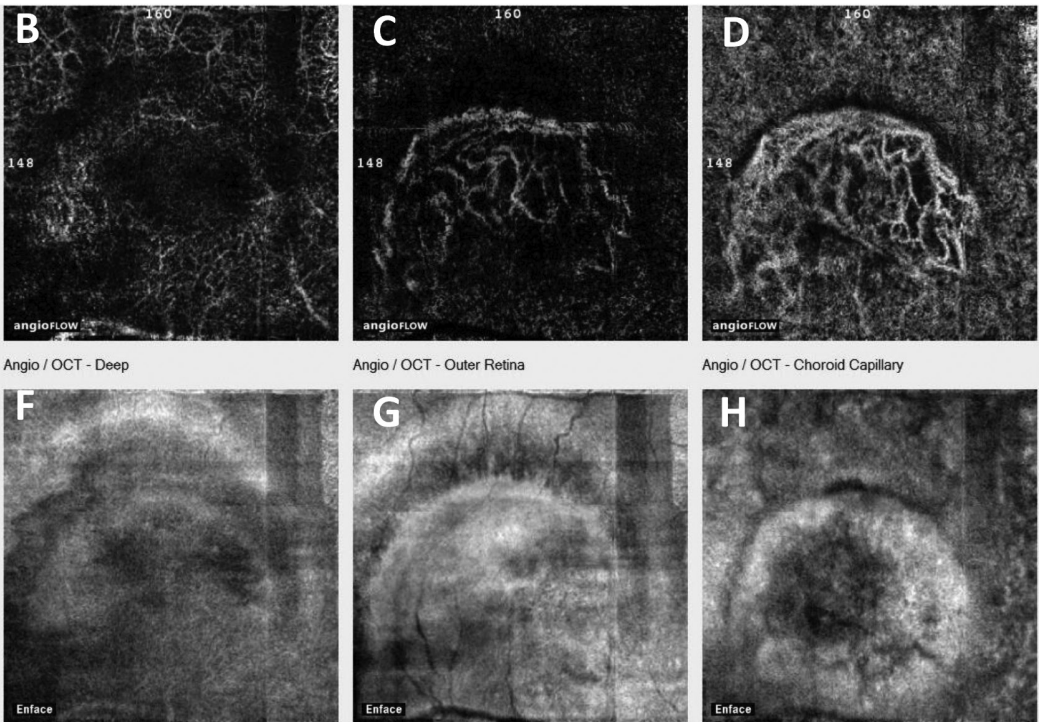

Angio / OCT - Choroid Capillary
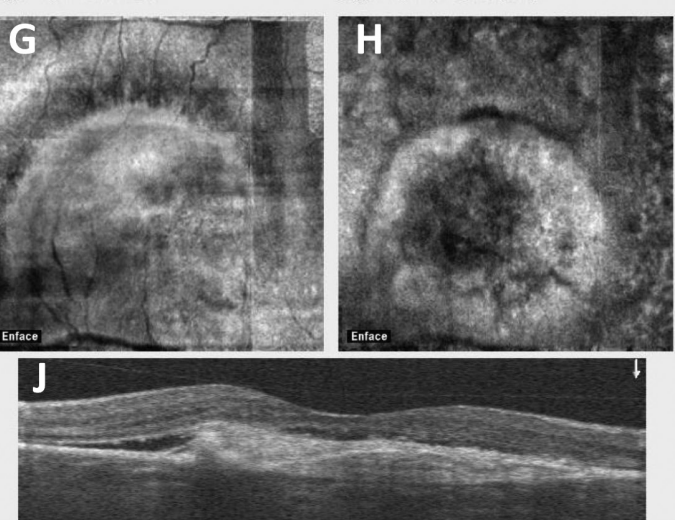

4. ábra

Jellemző kép kezelt AMD után: Heges forma. A)-D) OCT-A-felvételek. E)-H) En face OCT-felvételek. I)-J) OCT-felvételek

A) Felszínes retinaplexus - megtartott

B) Mély retinalis plexus - kiszélesedett fovealis avascularis zóna, anastomosisok

C) A retina mély rétege - sejthető/belevetül a régi $\mathrm{CNV}$, amely körül avascularis zóna húzódik

D) A choriocapillaris érhálózat - A vastagabb erekből felépülő korábbi, hegesedett $\mathrm{CNV}$

E)-H) En face OCT-felvételek az A)-D) felvétel síkjában. A heg és a retina síkjában kifejezett egyenetlenség látható

I)-J) Hagyományos OCT-felvételek a horizontális és vertikális síkokban. Elvékonyodott neuroretina alatt fusiformis hiperreflektív anyag, megfelel a heges CNV-nek. Kevés subretinalis folyadék is ábrázolódik, amely a CNV aktivitására utalhat 


\section{Eredmények}

A kezelt szemek átlagos legjobb korrigált visusa $58,2 \pm 18,6$ ETDRS-betú volt, igen nagy változatossággal. A legrosszabb látóélesség mindössze 20 betû volt, amely decimális értékben 0,04 értéknek felel meg, de volt csaknem teljes visusú szem is 89 betúvel, amely 1,0 látóélességnek felel meg.

A csökkent fixáció ellenére mind az 56 szem esetében értékelhető felvételt tudtunk készíteni. A hagyományos keresztmetszeti OCT-felvételen meghatároztuk, hogy a maculában az AMD milyen állapota figyelhető meg.

A felszínes retinaerek károsodását, az avascularis zóna kiszélesedését 5/56 esetben, a mélyebb retinakeringés részleges kiesését 9/56 esetben tapasztaltuk. Szembetünő, hogy míg a felszínes retinaplexus legtöbb esetben jól megtartotta szerkezetét az AMD hosszú távú kezelése mellett is, addig a mély retinaplexus nagyobb arányban volt érintett. Jellemző volt még az avascularis zóna szélén lévő anastomosisképződés.
A choriocapillaris és a környező szövetek károsodására, a CNV-t követő eltérésekre négyféle kép volt jellemző:

1. Pigmenthám- és choriocapillaris-atrophia $(49 / 56$ esetben). A legtöbb esetben a VEGF-gátló injekció hatására utal ez az eltérés. A sorvadt pigmenthám minden esetben kíséri a choriocapillaris sorvadását (3. ábra).

2. Submacularis heg (36/56 esetben) a CNV elzáródása után is kimutatható az esetek többségében az OCTA-felvételeken (4. ábra).

3. Aktív neovascularisatio (13/56 esetben). A CNV aktivitására elsősorban az intra- és subretinalis folyadék OCT-képe alapján következtethetünk. Magát a CNV-t pusztán az OCT-A-felvételeken láthatjuk olyan esetekben is, amikor folyadékgyülemmel nem jár együtt az elváltozás (5. ábra).

4. Intraretinalis ciszták (11/56 esetben). Eseteink között a retinában felhalmozódó folyadék kisebb arányban, de mégis jelentős számban fordult elő. A cisztoid úrök az érrendszert torzítva csaknem minden felvételen tetten

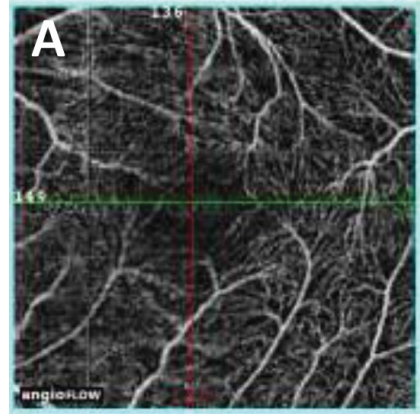

Ango / OCT - Supericial
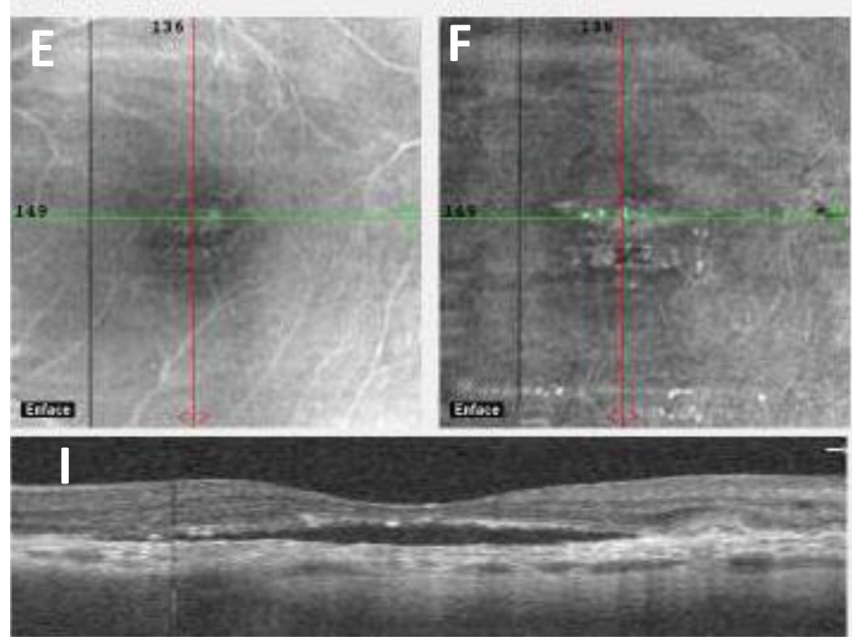

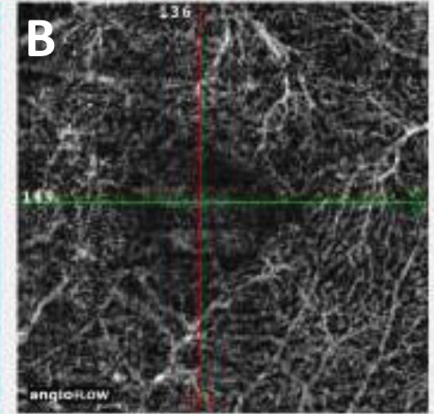

Ango / OCT - Deep

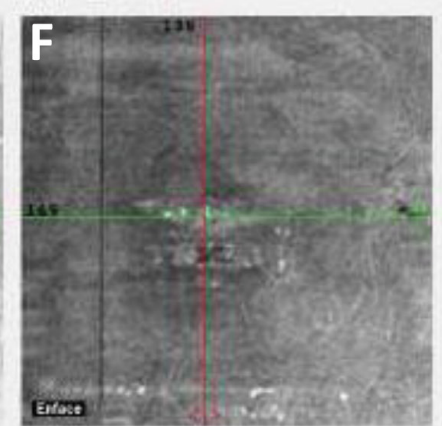

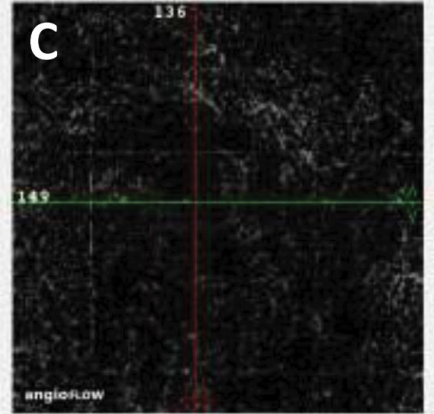

Ango / OCT - Outer Retina
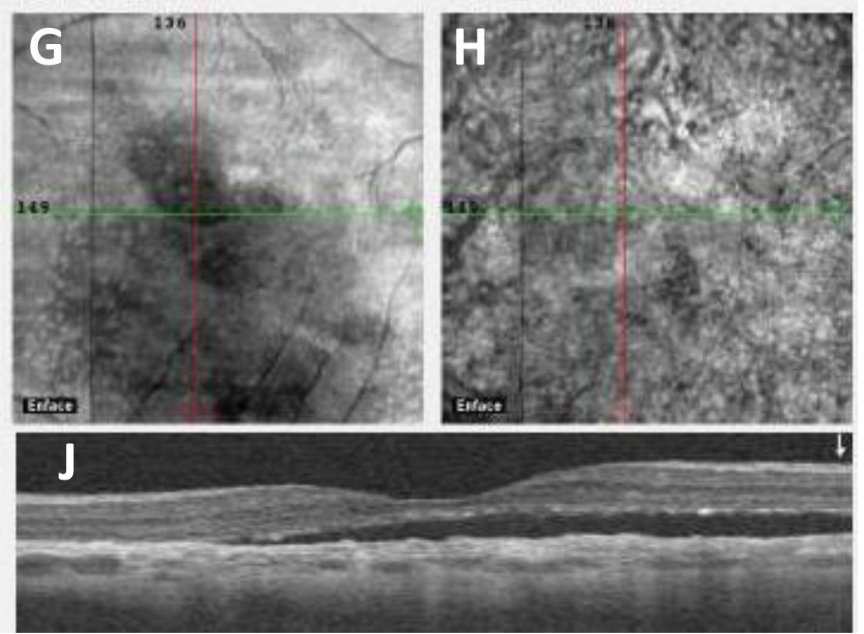

5. ábra

Jellemző kép kezelt AMD után: Kiújuló subretinalis folyadék, sorvadt neuroretina és pigmenthám. A)-D) OCT-A-felvételek. E)-H) En face OCTfelvételek. I)-J) OCT-felvételek

A) Felszínes retinaplexus - egyenetlen, kissé kiszélesedett érrendszer

B) Mély retinalis plexus - vastagabb, szabálytalan, egyenetlen erek megjelenése, anastomosisok

C) A retina mély rétege - a D) képen látszó CNV területében hiperreflektivitás

D) A choriocapillaris érhálózat - a bokorszerúen elágazó érújdonképződés, ágai között csökkent keringésú érhártya

E)-H) En face OCT-felvételek az A)-D) felvétel síkjában. E)-F) A felvételeken szemcsés hiperreflektivitás. G) A subretinalis folyadék határa látható. H) Pigmenthám károsodása

I)-J) Hagyományos OCT-felvételek a horizontális és vertikális síkokban. A fovea területében csökkent, körülötte kissé fokozott neuroretina-vastagság, tiszta subretinalis folyadék, a folyadék körül szemcsézettség. Egyenetlen pigmenthám és elvékonyodott chorioidea 

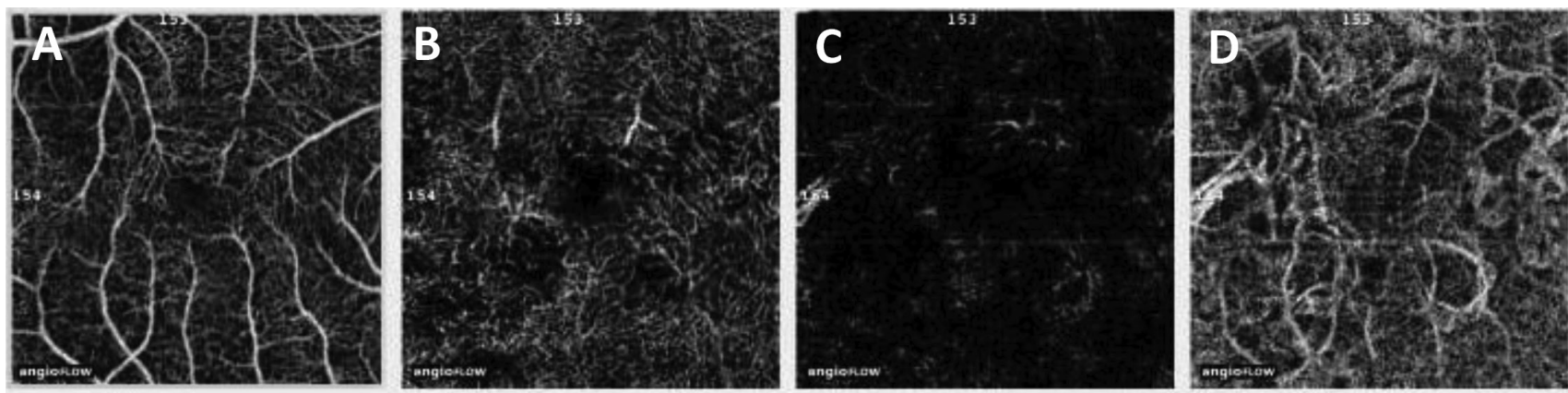

Ango/OCT-Superficial

Ango / OCT-Doop

Ango / OCT - Outer Retins

Ango/ CCT-Charaid Capilsy
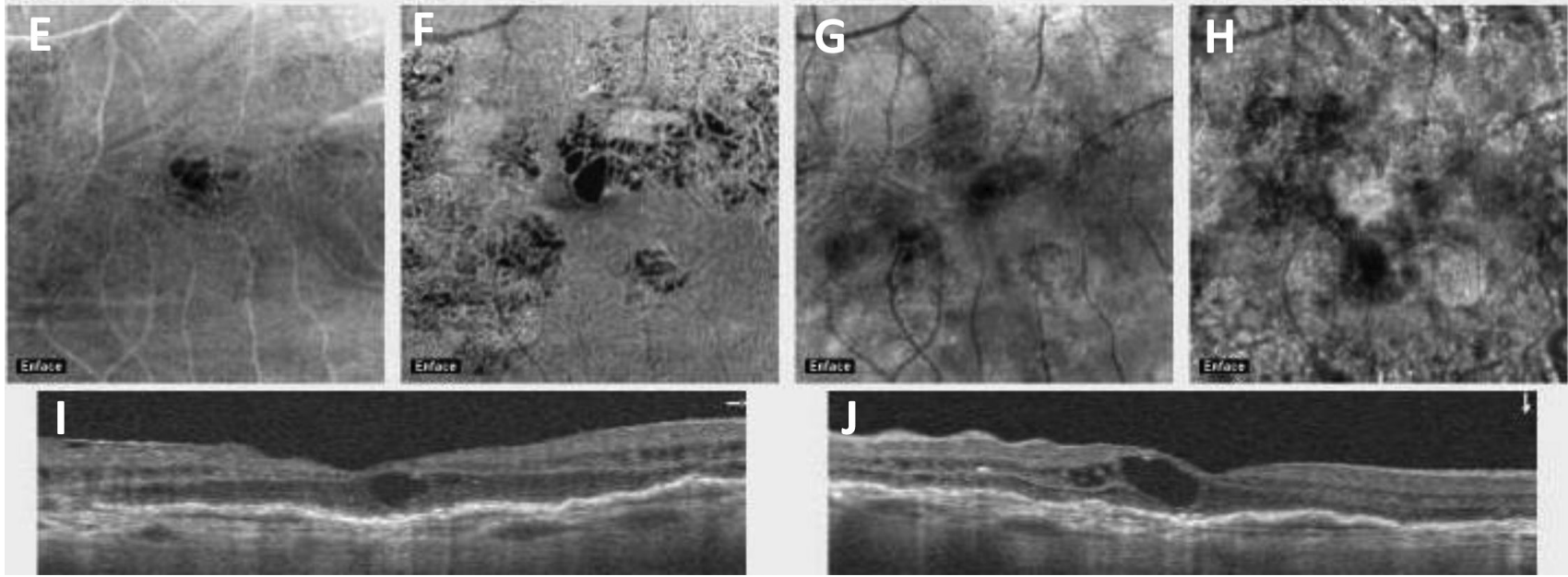

6. ábra
Jellemző kép kezelt AMD után: Intraretinalis oedema, atrophia és heg keveredése. A)-D) OCT-A-felvételek. E)-H) En face OCT-felvételek. I)-J) OCT-felvételek
A) Felszínes retinaplexus - kissé egyenetlen, de megtartott
B) Mély retinalis plexus - vastagabb, szabálytalan, helyenként elzáródott erek megjelenése, a ciszták területében avascularis zónák, körülöttük anasto- mosisok
C) A retina mély rétege - cisztoid oedemának megfelelően kevésbé reflektív területek
D) A choriocapillaris érhálózat - A vastagabb erekból és a fovea alatt hiányos keringésű choriocapillaris, korábbi, hegesedett CNV
E)-H) En face OCT-felvételek az A)-D) felvétel síkjában. Az intraretinalis ciszták sötéten ábrázolódnak, fóleg E) és G) felvételeken, a H) ábra a pigmenthám károsodását is jelzi
I)-J) Hagyományos OCT-felvételek a horizontális és vertikális síkokban. Fokozott neuroretina-vastagság, cisztoid úrök, egyenetlen pigmenthám és elvékonyodott chorioidea

érhetők, többek között az en face felvételeken is (6. ábra).

A négy jellegzetes forma keveredését tapasztaltuk legtöbb esetben. Az en face OCT-felvételek a sorvadás, az oedema és a heg megítélésében bizonyultak hasznosnak.

\section{Megbeszélés}

A nedves típusú AMD kialakulását követően 1-3 havi rendszerességgel szorulnak kontrollra az általánosságban idős betegek. A kontroll lényege a látás vizsgálata és a retina szerkezeti elemzése, annak érdekében, hogy a szükséges újrakezelésről idejében döntés születhessen. A rendszeres kontroll miatt elsődleges fontosságú, hogy az gyorsan és hatékonyan legyen elvégezhető. Ennek egyik új eszközét, az OCT-A-módszert mutattuk be közleményünkben.

Az OCT-A lényege, hogy nem invazív módon alkot képet a szemfenéki erekről, azaz a megszokott intravénás festékanyag beadására nincs szükség, hiszen az OCT-felvétel feldolgozásával kerül sor a képalkotásra. Mindezek által egy vizsgálat ötvözi a két korábbi módszer előnyös tulajdonságait.

A módszert az utóbbi években kezdték el rendszeresen alkalmazni, és számos eredményt közöltek egészséges szemek és AMD vonatkozásában egyaránt [16].

Az OCT-A pontos helye az AMD diagnosztikájában még nem teljesen tisztázott, az újfajta interpretáció szükségessége miatt egyelőre nem tudja teljesen kiváltani a fluoreszcens érfestéses vizsgálatokat [17].

Gong és mtsai [11] 86 szem elemzése kapcsán az OCTA specificitását 67,6\%-ra, szenzitivitását 86,5\%-ra értékelték, azaz volt olyan eset, amikor nem azonosították a CNV-t és olyan is akadt, amikor CNV-nek véleményezték az elváltozást annak ellenére, hogy az angiográfia nem mutatott ki szivárgást. A specificitás és szenzitivitás várhatóan javítható lesz a nagyobb tapasztalatszerzést követően. Az OCT-A pozitív prediktív értéke 80,4\%, 
míg negatív prediktív értéke 76,6\% volt értékelésük szerint.

De Carlo [18] tapasztalata szerint az OCT-A specificitása $90 \%$, szenzitivitása viszont mindössze $50 \%$, Coscas [19] szerint magas interobszerver egyezés volt az OCTA értékelésében. Spaide értékelésében [17] a két vizsgálómódszer nem helyettesíti egymást, de az interpretáció megértésében jelentős előrelépés várható. Sok új szempont merül fel ép macula vizsgálata kapcsán is. Samara és mtsai [20] 67 egészséges szem OCT-A-vizsgálata során azt tapasztalták, hogy az avascularis zóna mérete fordítottan arányos a macula vastagságával, ugyanakkor a fovealis avascularis zóna független volt az életkortól. Az ő eredményeik mellett szól Savastano munkája, aki a képszegmentáció megválasztására hívja fel a figyelmet [16].

Palejwala és mtsai [21] nagy kockázatú, nem exsudativ AMD-esetek vizsgálatakor 6\%-ban találtak olyan CNV-t, amely FA-n nem mutatott szivárgást, azonban mégis jelen volt, de nem volt aktív. Ez arra mutat rá, hogy bizonyos esetekben az OCT-A hamarabb kimutathatja az érújdonképződést, mint a hagyományos angiográfia.

Az FA és az OCT-A hatékonysága a CNV meghatározásában a fentiek alapján kihívást jelent frissen felismert, még nem kezelt nedves AMD eseteiben. A kezelt esetekben azonban tapasztalatunk alapján a CNV esetleges kiújulásának azonosítása még nehezebb feladat elé állítja a szemész kollégát. Vélhetôen a multimodális képalkotás lesz a célravezető, figyelembe véve elsősorban azt, hogy az újabb készülékek erre szimultán képesek.

Muakkassa és Lumbroso tanulmányai a különböző típusú CNV méretváltozásait követik nyomon [12, 22]. Muakkassa azt tapasztalta, hogy a CNV legnagyobb lineáris kiterjedése (greatest linear dimension - GLD) 23,6\%-os, míg a CNV összterülete 29,8\%-os csökkenést mutatott 3 hónapos VEGF-gátló kezelés kapcsán. Huang az individuális VEGF-adagolás módjára is lehetőséget lát, hiszen az OCT-A segítségével heti szinten nyomon követhető a CNV méretváltozása, így meghatározható, kinek hány hetente lesz várhatóan újrakezelésre szüksége [23].

Érdekes adat, hogy az OCT és a hagyományos angiográfia szerint hegnek tartott subretinalis szövetben az esetek 93,8\%-ában mutatott ki Miere OCT-A készülék segítségével CNV-t [24].

Hosszú távú VEGF-gátló kezelés mellett a felszínes retinakeringés megtartott állapotát tapasztaltuk. Ezzel szemben a mély retinaerek károsodása az esetek nagyobb arányában volt kimutatható. A chorioidea szintjében a betegség hátterében lévő érújdonképződés vagy az annak helyét kitöltő heg, illetve atrophia igazolódott. A noninvazív OCT-angiográfia elsősorban azon esetekben nyújt segítséget, amelyekben a betegség kiújulásának következtében az újrakezelés indikációjának felállítása kérdéses.
A hagyományos angiográfiában nem külön értékelt felszínes és mély retinaérplexusok újabb teret adnak az elemzéseknek. Míg a felszínes plexusok az idegrostrétegben találhatók, az erek átmérője nagyobb, átlagosan 75 $\mu \mathrm{m}$, addig a mélyebb plexus a ganglionsejtek rétegében helyezkedik el és jóval kisebb, körülbelül 20 um átmérőjü erek alkotják [16].

Képalkotási nehézséget jelenthet a törőközegek homályossága, például előrehaladott szürke hályog. Ilyen tekintetben az OCT-A nem különbözik az FA-tól. Az OCT-A kétségtelen előnye, hogy nehezen táguló pupilla esetében is jó képalkotás lehetséges, míg angiográfia esetén a funduskamerák többsége nem tud jó képet készíteni.

Mütermékhez vezethet a magas pigmenthám-elemelkedés vagy a kifejezett vérzés, hiszen ezekben az esetekben a kép szegmentációjába hiba csúszhat [25].

További értékelésre adhat módot az érújdonképződéseket alkotó erek vastagságának, illetve az áramlás gyorsaságának vizsgálata, amely prognosztikai jel lehet a CNV aktivitására, így látásrontó hatására vonatkozóan.

Érdekesség a CNV határán megjelenő anastomosis, ami FA esetében kevésbé szembetűnő jelenség. Szintén könnyebben azonosítható a tápláló fó ér, ami a CNV elsődleges forrását jelenti, és érdekessége, hogy tartós VEGF-gátló kezelés és OCT-felvételen kizárható folyadék mellett is kimutatható [26]. Feltételezik, hogy a tápláló ér felépítése nagymértékben eltér a CNV VEGF-gátló hatásra elzáródó többi, kisebb lumenű érhez képest, amelynek feltételezett oka a nagyobb mértékü pericytaborítás, amely megakadályozza a VEGF-gátló molekulák hozzáférését az érendothelhez. Ezen ércsoport múködésének pontosabb megértésében potenciális új utat nyit az OCT-A alkalmazása, amely arra is magyarázatot szolgáltathat, miért vannak olyan esetek, amelyek nem reagálnak kellőképpen a megszokott kezelésre.

Anyagi támogatás: A közlemény megírása és a kutatómunka anyagi támogatásban nem részesült.

Szerzôi munkamegosztás: R. M., N. Cs., B. Gy., E. M., B. Á., G. Zs., Sz. A., N. Z. Zs., P. A.: Betegvizsgálat lefolytatása. R. M., N. Cs., P. A.: Képelemzés. R. M., N. Cs., G. Zs., B. Á.: Adatrögzítés. R. M.: Statisztikai elemzés. B. A.: Adatelemzés, a kézirat megírása, ellenőrzés. R. M., N. Z. Zs.: A kézirat és az ábrák elkészítése. A cikk végleges változatát valamennyi szerző elolvasta és jóváhagyta.

Érdekeltségek: A szerzőknek nincsenek érdekeltségeik.

\section{Köszönetnyilvánítás}

A szerzők köszönik Jenei Erikának, a Szemészeti Klinika asszisztensnőjének odaadó munkáját a felvételek elkészítésében. 


\section{Irodalom}

[1] Kiss, H., Németh, J.: Causes of blindness in Hungary. [A vakság okai Magyarországon.] Szemészet, 2013, 150(3), 103-110. [Hungarian]

[2] Do, D. V.: Detection of new-onset choroidal neovascularization. Curr. Opin. Ophthalmol., 2013, 24(3), 244-247.

[3] Ferris, F. L. 3rd, Fine, S. L., Hyman, L.: Age-related macular degeneration and blindness due to neovascular maculopathy. Arch. Ophthalmol., 1984, 102(11), 1640-1642.

[4] Marmor, M. F., Ravin J. G.: Fluorescein angiography: insight and serendipity a half century ago. Arch. Ophthalmol., 2011, 129(7), 943-948.

[5] Huang, D., Swanson, E. A., Lin, C. P., et al.: Optical coherence tomography. Science, 1991, 254(5035), 1178-1181.

[6] Békési, L., Biró, A., Berta, A.: Ophthalmic application of optical coherence tomography. [Az optikai koherencia tomográfia szemészeti alkalmazásáról.] Szemészet, 1998, 135(3), 173-177. [Hungarian]

[7] Somfai, G. M., Salacz, G.: Optical biopsy of the retina in vivo: on optical coherence tomography and its clinical use in ophthalmology. [A retina optikai biopsziája in vivo: az optikai koherencia tomográfiáról és annak szemészeti alkalmazásáról.] Orv. Hetil., 2005, 146(21), 1157-1163. [Hungarian]

[8] Schmidt-Erfurth, U., Chong, V., Loewenstein, A., et al.: Guidelines for the management of neovascular age-related macular degeneration by the European Society of Retina Specialists (EURETINA). Br. J. Ophthalmol., 2014, 98(9), 1144-1167.

[9] Makita, S., Hong, Y., Yamanari, M., et al.: Optical coherence angiography. Opt. Express, 2006, 14(17), 7821-7840.

[10] Jia, Y., Tan, O., Tokayer, J., et al.: Split-spectrum amplitudedecorrelation angiography with optical coherence tomography. Opt. Express, 2012, 20(4), 4710-4725.

[11] Gong, J., Yu, S., Gong, Y., et al.: The diagnostic accuracy of optical coherence tomography angiography for neovascular age-related macular degeneration: a comparison with fundus fluorescein angiography. J. Ophthalmol., 2016, 2016, 7521478.

[12] Muakkassa, N. W., Chin, A. T., de Carlo, T., et al.: Characterizing the effect of anti-vascular endothelial growth factor therapy on treatment-naive choroidal neovascularization using optical coherence tomography angiography. Retina, 2015, 35(11), 22522259.

[13] Lukács, R., Resch, M., Papp, A., et al.: Long term intravitreal ranibizumab treatment for exsudative age-related macular degeneration. [Hosszú távú intravitrealis ranibizumabkezelés exsudativ időskori maculadegenerációban.] Orv. Hetil., 2013, 154(45), 1790-1797. [Hungarian]

[14] Lukács, R., Tóth-Kovács, K., Pámer, Zs.: Correlation between morphologic and functional improvements in patients with agerelated macular degeneration treated with intravitreal antiVEGF injection. [Anatómiai és funkcionális javulás korrelációja intravitrealis VEGF-gátló injekcióval kezelt időskori maculadegene- rációban szenvedő betegeknél.] Szemészet, 2010, 147(3-4), 127-132. [Hungarian]

[15] Jia, Y., Bailey, S. T., Wilson, D. J., et al.: Quantitative optical coherence tomography angiography of choroidal neovascularization in age-related macular degeneration. Ophthalmology, 2014, $121(7), 1435-1444$

[16] Savastano, M. C., Lumbroso, B., Rispoli, M.: In vivo characterization of retinal vascularization morphology using optical coherence tomography angiography. Retina, 2015, 35(11), 21962203.

[17] Spaide, R. F., Klancnik, J. M. Jv., Cooney, M. J.: Retinal vascular layers imaged by fluorescein angiography and optical coherence tomography angiography. JAMA Ophthalmol., 2015, 133(1), $45-50$.

[18] De Carlo, T. E., Bonini Filho, M. A., Chin, A. T., et al.: Spectraldomain optical coherence tomography angiography of choroidal neovascularization. Ophthalmology, 2015, 122(6), 1228-1238.

[19] Coscas, G. J., Lupidi, M., Coscas, F., et al.: Optical coherence tomography angiography versus traditional multimodal imaging in assessing the activity of exudative age-related macular degeneration: a new diagnostic challenge. Retina, 2015, 35(11), 22192228.

[20] Samara, W. A., Say, E. A., Khoo, C. T., et al.: Correlation of foveal avascular zone size with foveal morphology in normal eyes using optical coherence tomography angiography. Retina, 2015, 35(11), 2188-2195.

[21] Palejwala, N. V., Jia, Y., Gao, S. S., et al.: Detection of non-exudative choroidal neovascularization in age-related macular degeneration with optical coherence tomography angiography. Retina, 2015, 35(11), 2204-2211.

[22] Lumbroso, B., Rispoli, M., Savastano, M. C.: Longitudinal optical coherence tomography-angiography study of type 2 naive choroidal neovascularization early response after treatment. Retina, 2015, 35(11), 2242-2251.

[23] Huang, D., Jia, Y., Rispoli, M., et al.: Optical coherence tomography angiography of time course of choroidal neovascularization in response to anti-angiogenic treatment. Retina, 2015, 35(11), 2260-2264.

[24] Miere, A., Semoun, O., Cohen, S. Y., et al.: Optical coherence tomography angiography features of subretinal fibrosis in age-related macular degeneration. Retina, 2015, 35(11), 2275-2284.

[25] Spaide, R. F., Fujimoto, J. G., Wabeed, N. K.: Image artifacts in optical coherence tomography angiography. Retina, 2015, 35(11), 2163-2180.

[26] Spaide, R. F.: Optical coherence tomography angiography signs of vascular abnormalization with antiangiogenic therapy for choroidal neovascularization. Am. J. Ophthalmol., 2015, 160(1), 6-16.

(Resch Miklós dr.,

Budapest, Üllői út 26., 1085

Budapest, Pf. 2, 1428

e-mail: miklosresch@gmail.com) 